University of Nebraska - Lincoln

DigitalCommons@University of Nebraska - Lincoln

\title{
Cool-season whole-plant gas exchange of exotic and native semiarid bunchgrasses
}

\author{
Erik P. Hamerlynck \\ USDA-ARS Southwest Watershed Research Center, erik.hamerlynck@ars.usda.gov \\ Russell L. Scott \\ USDA-ARS Southwest Watershed Research Center
}

Greg A. Barron-Gafford

University of Arizona

Michelle L. Cavanaugh

USDA-ARS Southwest Watershed Research Center

M. Susan Moran

USDA-ARS Southwest Watershed Research Center

See next page for additional authors

Follow this and additional works at: https://digitalcommons.unl.edu/usdaarsfacpub

Hamerlynck, Erik P.; Scott, Russell L.; Barron-Gafford, Greg A.; Cavanaugh, Michelle L.; Moran, M. Susan; and Huxman, Travis E., "Cool-season whole-plant gas exchange of exotic and native semiarid bunchgrasses" (2012). Publications from USDA-ARS / UNL Faculty. 1255.

https://digitalcommons.unl.edu/usdaarsfacpub/1255

This Article is brought to you for free and open access by the U.S. Department of Agriculture: Agricultural Research Service, Lincoln, Nebraska at DigitalCommons@University of Nebraska - Lincoln. It has been accepted for inclusion in Publications from USDA-ARS / UNL Faculty by an authorized administrator of DigitalCommons@University of Nebraska - Lincoln. 


\section{Authors}

Erik P. Hamerlynck, Russell L. Scott, Greg A. Barron-Gafford, Michelle L. Cavanaugh, M. Susan Moran, and Travis E. Huxman 


\title{
Cool-season whole-plant gas exchange of exotic and native semiarid bunchgrasses
}

\author{
Erik P. Hamerlynck • Russell L. Scott • Greg A. Barron-Gafford • \\ Michelle L. Cavanaugh • M. Susan Moran - Travis E. Huxman
}

This article is a U.S. government work, and is not subject to copyright in the United States.

Received: 20 September 2011/Accepted: 13 June 2012/Published online: 3 July 2012

(C) Springer Science+Business Media B.V.(outside the USA) 2012

\begin{abstract}
The success of invasive aridland plants may depend on their utilization of precipitation not fully exploited by native species, which could lead to seasonally altered ecosystem carbon and water fluxes. We measured volumetric soil water across $25-\mathrm{cm}$ profiles $\left(\theta_{25 \mathrm{~cm}}\right)$ and springtime whole-plant water- and carbon-fluxes of the exotic Lehmann lovegrass (Eragrostis lehmanniana) and a native bunchgrass, bush muhly (Muhlenbergia porteri), following typical (55 mm in 2009) and El Niño-enhanced accumulations (154 mm in 2010) in a SE Arizona savanna. Across both years, $\theta_{25 \mathrm{~cm}}$ was higher under lovegrass plots, with similar evapotranspiration (ET) between lovegrass and bush muhly plots. However, in 2010 transpiration (T) was higher in bush muhly than lovegrass, implying higher soil evaporation in lovegrass plots maintained similar ET. Net ecosystem carbon dioxide exchange (NEE) was similar between lovegrass and bush muhly plots in 2009, but was more negative in bush muhly plots following El Niño, indicating greater $\mathrm{CO}_{2}$ assimilation. Ecosystem respiration $\left(R_{\text {eco }}\right)$ and gross ecosystem photosynthesis
\end{abstract}

E. P. Hamerlynck $(\bowtie) \cdot$ R. L. Scott ·

M. L. Cavanaugh · M. Susan Moran

USDA-ARS Southwest Watershed Research Center,

Tucson, AZ, USA

e-mail: erik.hamerlynck@ars.usda.gov

G. A. Barron-Gafford · T. E. Huxman

Biosphere2 Earthscience, University of Arizona, Tucson, AZ, USA
(GEP) were similar between lovegrass and bush muhly plots in 2009, but were higher in bush muhly plots in 2010. As a result, lovegrass plots reduced ecosystem water-use efficiency $\left(\mathrm{WUE}_{\mathrm{e}}=\mathrm{NEE} / \mathrm{ET}\right)$, while bush muhly $\mathrm{WUE}_{\mathrm{e}}$ remained constant between 2009 and 2010. Concurrent whole-plant WUE $\left(\mathrm{WUE}_{\mathrm{p}}=\mathrm{GEP} / T\right)$ did not change in lovegrass plots, but increased in bush muhly plots between these years. We concluded that cool-season precipitation use is not a component of Lehmann lovegrass invasive success, but that the change in ET partitioning and attendant shifts in cool-season $\mathrm{WUE}_{\mathrm{e}}$ may increase interannual variation in ecosystem water- and carbon-exchange dynamics in the water-limited systems it dominates.

Keywords Bush muhly - Evapotranspiration · Lehmann lovegrass · Photosynthesis · Respiration · Savanna $\cdot$ Soil water

\section{Introduction}

The seasonal distribution and interannual variation in precipitation is an important determinant of plant community and ecosystem dynamics in aridland systems (Neilson 1987). Across the arid and semiarid southwest United States, El Niño/Southern Oscillation (ENSO) events markedly increase the amount of coolseason precipitation (Sheppard et al. 2002). The long duration and large areal extent of these low-intensity 
storms are critical to seasonal recharge of deeper soil moisture and ground water (Neilson 1987; Scott et al. 2000; Seyfried et al. 2005). Cool-season precipitation has differential effects to ecosystem function; evergreen and cool-season active shrubs readily use coolseason precipitation, while cold temperatures can limit periods warm-season grasses can exploit this precipitation (Muldavin et al. 2008). ENSO-enhanced precipitation can favor spread of invasive grasses into shrub-dominated systems (Huxman and Smith 2001; DeFalco et al. 2007), as well as facilitate woody plant encroachment into grass-dominated systems (Holmgren et al. 2006; Marshall et al. 2008).

Such dramatic changes in vegetative structure can alter the partitioning and regulation of ecosystem water- and carbon-fluxes in arid and semiarid systems (Huenneke et al. 2002; Huxman et al. 2005; Seyfried et al. 2005; Jenerette et al. 2008). In contrast, the ecosystem-level consequences of replacement of native semiarid perennial grasses by exotic perennial grasses are not as well studied as grass/shrub (e.g., cheat grass and sage brush; Prater and DeLucia 2006) and shrub/grass replacements (e.g., mesquite expansion into semi-desert grassland; Huxman et al. 2005). This is surprising, given that there is good early work showing invasive bunchgrasses have growth patterns that facilitate higher water extraction to sustain higher whole-plant carbon uptake and growth, which could potentially alter ecosystem water- and carbon-fluxes (Caldwell et al. 1981, 1983; Anderson et al. 1987; Anderson and Toft 1993). An exception to this is the expansion of the South African bunchgrasses across southwest US desert grasslands. These grasses possess ecophysiological and growth characteristics (e.g., high leaf-level gas exchange and rapid biomass accumulation rates) that have the potential to transform ecosystem carbon and water fluxes (Williams and Baruch 2000). One of these grasses, Lehmann's lovegrass (Eragrostis lehmanniana), presents a serious ecological disturbance that dramatically reduces floral and faunal diversity of the areas it dominates (Bock et al. 1986; Anable et al. 1992; Flanders et al. 2006). Experimental summer monsoon-season rainfall pulse studies show Lehmann's lovegrass plots have lower net ecosystem carbon exchange (NEE) integrated over post-rainfall periods, due to higher ecosystem respiratory fluxes (Huxman et al. 2004; Potts et al. 2006), and higher soil evaporative contributions to evapotranspiration (ET) compared to other native warm-season grasses (Yepez et al. 2005; Moran et al. 2009). These ecosystem-level results need to be reconciled to those showing $2-4 \times$ higher net annual primary productivity associated with Lehmann lovegrass invasive success (Cox et al. 1990; Cox and Ruyle 1996; McClaran 2003) and higher cool-season ET in lovegrass-dominated stands, conjectured to stem from higher plant transpiration (T) from cool-season leaf cohorts (Frasier and Cox 1994). Some have suggested that effective use of cool-season precipitation is an important component to higher productivity that facilitates the invasive success of this grass (Anable et al. 1992; Frasier and Cox 1994), though some studies suggest otherwise (Cox et al. 1990). Additionally, several native semiarid $\mathrm{C}_{4}$ grasses also retain cool-season green tissue, and may have photosynthetic characteristics that could facilitate cool-season activity (Miller and Donart 1981; Fernandez and Reynolds 2000; Taub 2000).

Here, we present a study comparing whole-plant gas exchange of Lehmann lovegrass and a native grass, bush muhly (Muhlenbergia porteri) over two consecutive spring-time periods, the first following normal cool-season rainfall, and the second following ENSO conditions. The purpose of this study was twofold; first, we wished to ascertain if Lehmann lovegrass had consistently greater cool-season activity compared to a native species. Second, we ascertained how responses of these two species to ENSO conditions may alter ecosystem function. Both bunchgrasses are drought tolerant, warm-season grasses that can initiate cool-season leaf cohorts (Miller and Donart 1981; Frasier and Cox 1994), and therefore present a valid comparison for determining if the exotic lovegrass is better able to use cool-season precipitation than a native grass. In order to quantify the effects of lovegrass dominance on ecosystem carbon- and waterfluxes, we measured whole-plant NEE and ET, and ecosystem respiration $\left(R_{\text {eco }}\right)$ to determine gross ecosystem photosynthesis $\left(\mathrm{GEP}=-1 *\left(\mathrm{NEE}-R_{\mathrm{eco}}\right)\right.$ ), and bare soil evaporation (E) to estimate whole-plant $\mathrm{T}(T=\mathrm{ET}-E)$ on plots dominated by one or two individuals of Lehmann's lovegrass and bush muhly. If Lehmann's lovegrass does more effectively use cool-season rains, we could expect it to have higher springtime GEP and greater T contributions to ET than bush muhly, potentially altering the trade off between ecosystem carbon uptake and water loss (water-use efficiency; $\mathrm{WUE}_{\mathrm{e}}=\mathrm{GEP} / \mathrm{ET}$ ), an important component 
of ecosystem resilience to climate variation (Monson et al. 2010).

\section{Materials and methods}

Site description

Field work was conducted at the USDA-ARS Santa Rita mesquite savanna site $\left(31.821^{\circ} \mathrm{N}, 110.866^{\circ} \mathrm{W}\right.$, elevation: $1116 \mathrm{~m} \mathrm{ASL}$ ) on the Santa Rita Experimental Range (SRER), 45-km south of Tucson, Arizona. The site is representative of desert grassland conversion to savanna following a century of velvet mesquite (Prosopis velutina) expansion across SRER (McClaran 2003). The site has a mesquite overstory (ca. $35 \%$ cover), with a ground-layer dominated by native $\mathrm{C}_{4}$ grasses and Lehmann lovegrass, with scattered sub-shrubs of burroweed (Isocoma tenuisecta), prickly pear (Opuntia engelmannnii), and barrel cactus (Ferocactus wislizeni). Soils are Combate series; well-drained coarse-loamy, mixed, non-acid Ustic Torrifluvents (Breckenfeld and Robinett 2003). The site is in SRER Pasture 2N, which was grazed yearround from 1957 to 2005 (ca. 0.028 cattle ha $\mathrm{y}^{-1}$ ), and fenced in 2008.

Climate context and volumetric soil moisture

Mean annual precipitation is $377 \mathrm{~mm}$ (1937-2007), measured at SRER rain-gauge \#45, located $0.5-\mathrm{km}$ ESE from the site. We used monthly January 1937 to April 2010 data from this gauge to calculate standardized precipitation index (SPI) for 1-, 2-, 3-, 4-, and 5-month intervals from December 1 to April 30, the period associated most of the regional winter precipitation (Sheppard et al. 2002). SPI allows comparison to systems with different precipitation regimes; for any given time period, SPI of -0.99 to +0.99 indicates near-normal rainfall, +1.0 to 1.49 and -1.0 to -1.49 moderately wet and dry conditions, +1.5 to +1.99 and -1.5 to -1.99 very wet and severely dry conditions, and values exceeding +2.0 and -2.0 extremely wet or dry conditions (McKee et al. 1993).

Minimum and maximum air temperature $\left(T_{\min }\right.$ and $T_{\max }$ ) were measured with a shaded, aspirated Vaisala HMP35D temperature/humidity probe (Vaisala, Helsinki, Finland) $3 \mathrm{~m}$ above the soil surface, and individual rainfall totals were measured with a tipping bucket rain-gauge, with data recorded on a CR-10X data-logger (Campbell Scientific, Logan, Utah) at an eddy-covariance tower located $40-\mathrm{m} \mathrm{NW}$ of the study site. Volumetric soil moisture of $25-\mathrm{cm}$ soil profiles $\left(\theta_{25 \mathrm{~cm}}\right)$ was measured continuously with a Campbell TDR-100 time domain reflectometer (TDR) system controlled by a data-logger (Campbell Scientific, Logan Utah). TDR waveguides were deployed 24-27 May, 2008; probes were inserted at $60^{\circ}-70^{\circ}$ from horizontal into soil underneath a single grass bunch within four individual $0.75 \times 0.75 \mathrm{~m}^{2}$ plots containing 1-2 individual Lehmann lovegrass or bush muhly plants, and in four bare soil plots. All plots were within a ca. $16 \times 12 \mathrm{~m}\left(176 \mathrm{~m}^{2}\right)$ fenced, level area located on the same geomorphic surface to ensure soil homogeneity, and separated by at least $3 \mathrm{~m}$ to insure spatial independence; plot-size matched that of the whole-plant gas-exchange chamber base (described below). Waveforms were generated every $30 \mathrm{~min}$, converted to $\theta$ data $\left(\mathrm{cm}^{3} \mathrm{~cm}^{-3}\right)$. Annual plants were removed regularly to insure clear grass or bare soil signals.

Ecosystem and whole-plant gas exchange

Following initiation of leaf growth in both species in the early spring, ecosystem $\mathrm{CO}_{2}$ - and $\mathrm{H}_{2} \mathrm{O}$-fluxes were measured on the monitored lovegrass, bush muhly, and bare soil plots ca. every 2 weeks using protocols similar to Huxman et al. (2004) and Potts et al. (2006). Mid-morning flux measurements (10:00-13:00 MST) were made from February 3 to April 10, 2009 (normal year) and from February 24 to May 24, 2010 following strong ENSO conditions (El Niño year). These sampling periods encompass spring periods typically associated with aridland plant activity following winter rains (Neilson 1987; Smith et al. 1997). Carbon- and water-vapor fluxes were estimated by measuring changes in $\mathrm{CO}_{2}$ and $\mathrm{H}_{2} \mathrm{O}$ concentration with a Li7500 open-path IRGA (LiCOR Instruments, Lincoln, Nebraska) following enclosure of the plot with a $0.75 \times 0.75 \times 0.75 \mathrm{~m}\left(0.422 \mathrm{~m}^{3}\right)$ chamber of tightly sewn polyethylene held taut in a PVC pipe tent frame (Shelter Systems, Santa Cruz, CA). Chamber material allowed $92 \%$ of photosynthetically active radiation to pass into the plots, while allowing infrared (IR) radiation to escape (Potts et al. 2006). A fan ensured atmospheric mixing after enclosure and sealing the chamber base with a chain. Chamber air 
was mixed for $30 \mathrm{~s}$ prior to a 90 -s flux measurement. The chamber was then removed, aerated for ca. $1 \mathrm{~min}$, re-placed over the plot, sealed, and shaded with a blanket to repeat measurements in the dark. Ambientlight fluxes allowed estimation of NEE and ET; measurements in the dark gave ecosystem respiration $\left(R_{\text {eco }}\right)$ needed to estimate GEP (GEP $=-1 *$ $\left(\mathrm{NEE}-R_{\mathrm{eco}}\right)$ ). Bare soil measurements estimated soil $\mathrm{E}$ and $\mathrm{T}(T=\mathrm{ET}-\mathrm{E})$. Such mid-day measurements are good predictors of daily integrated values, and can be extrapolated across several days' activity (Huxman et al. 2004; Potts et al. 2006).

\section{Statistical analysis}

2009 and 2010 daily $T_{\max }$ and $T_{\min }$ were compared using one-way analysis of variance (ANOVA, Statistix v 8.0, Analytical Software, Tallahassee, FL), and by regressing $T_{\max }$ against $T_{\min }$ and comparing slopes and intercepts obtained for each year (linear regression, Statistix v.8.0). Two-way ANOVA was used to compare $\theta_{25 \mathrm{~cm}}$ between 2009 and 2010 of Lehmann's lovegrass and bush muhly plots. $\theta_{25 \mathrm{~cm}}$ data from December 13, 2008 to May 4, 2009 were compared to those from January 14 to May 24, 2010; these included 5 days prior to the first rain of each study period, and span the plant active period for each year. All $\theta_{25 \mathrm{~cm}}$ data were arcsine transformed to meet ANOVA data distribution assumptions (Zar 1974).

Split-plot, repeated-measures ANOVA (Statistix v.8.0) was used to test for interannual differences in water and carbon gas exchange of Lehmann lovegrass and bush muhly plots. The between-treatment (wholeplot) effect was species (Lehmann lovegrass vs. bush muhly), using the species-by-replicate plot interaction as the whole-plot error term to test for differences pooled across all dates, with an associated $\alpha$ of 0.05 . The within-treatment (sub-plot) factors were year (2009 and 2010), and species-by-year interaction, using the species-by-year-by-replicate plot interaction as the sub-plot error term. Of specific interest were speciesby-year interactions, which would indicate speciesspecific interannual activity; $\alpha$-adjusted general linear contrasts (Scheffe's $F$ ) tested specific contrasts contributing to any species-by-year interaction.

Ecosystem water-use efficiency $\left(\mathrm{WUE}_{\mathrm{e}}\right)$ was determined by regressing GEP against ET and plant wateruse efficiency $\left(\mathrm{WUE}_{\mathrm{p}}\right)$ by regressing GEP against $\mathrm{T}$, across both species and years and comparing the slope and intercepts of each species/year combination using a $F$ test procedure (linear regression, Statistix v.8.0). Specific pair-wise slope comparisons were made using Tukey's test (HSD), following the criteria described in Zar (1974). Standard errors to calculate HSD were made using the pooled SS, with HSD scores needing to exceed 3.79 to be significant at $p \leq 0.05$ (Zar 1974).

\section{Results}

December to April total rainfall was $55.2 \mathrm{~mm}$ in 2009 (Fig. 1a) and $154.2 \mathrm{~mm}$ in 2010 (Fig. 1b). 2009 accumulations were slightly below normal (5-month SPI $=-0.58$ ), and above normal in 2010 $(\mathrm{SPI}=1.12)$, the 56th and 12th ranked DecemberApril accumulations over the 73-year record. Low SPI in 2009 was due to dry March conditions $(2.7 \mathrm{~mm}$; 1 -month SPI $=-0.91$ ) coupled with otherwise nearnormal rainfall, ranging from SPI $=0.23$ for February $2009(17.9 \mathrm{~mm})$ to -0.20 for January 2009 (10.5 mm; Fig. 1a). In 2010, December had lower than average precipitation $(6.7 \mathrm{~mm}$; 1-month SPI $=-0.75)$, but the following 4 months were very wet (4-month SPI $=1.58)$, the 4 th wettest January 1 to April 30 period in the record, with accumulations of 84.5, 37.6, 12.8, and $12.6 \mathrm{~mm}$ for January, February, March, and April, respectively (Fig. 1b).

NEE did not differ between lovegrass and bush muhly plots pooled across both years $(-0.8 \mu \mathrm{mol}$ $\mathrm{m}^{-2} \mathrm{~s}^{-1} \pm 0.09 \mathrm{SE}$ and $-1.2 \mu \mathrm{mol} \mathrm{m} \mathrm{m}^{-2} \mathrm{~s}^{-1} \pm 0.11$ SE for lovegrass and bush muhly, respectively), or between years pooled across species, but showed a significant species-by-time interaction (Table 1). This was due to more negative lovegrass NEE in 2009 $\left(-1.2 \mu \mathrm{mol} \mathrm{m}{ }^{-2} \mathrm{~s}^{-1} \pm 0.11 \mathrm{SE}\right.$; Fig. 1a) compared to $2010\left(-0.5 \mu \mathrm{mol} \mathrm{m}{ }^{-2} \mathrm{~s}^{-1} \pm 0.11 \mathrm{SE}\right.$; Fig. 1b) (Scheffe's $F=26.6 ; p=0.014$ ), a pattern not apparent in bush muhly plots $\left(-1.0 \mu \mathrm{mol} \mathrm{m} \mathrm{m}^{-2} \mathrm{~s}^{-1} \pm 0.11\right.$ $\mathrm{SE}$ and $-1.4 \mu \mathrm{mol} \mathrm{m} \mathrm{m}^{-2} \mathrm{~s}^{-1} \pm 0.17 \mathrm{SE}$ for 2009 and 2010, respectively) (Scheffe's $F=1.79 ; p=0.27$; Fig. 1a, b). Also, in 2010, bush muhly NEE was more negative than lovegrass NEE (Scheffe's $F=24.9$; $p=0.015$; Fig. 1b), while in 2009, bush muhly NEE was similar to that in lovegrass plots (Scheffe's $F=0.27 ; p=0.64$; Fig. 1a).

Springtime plant activity was delayed in 2010, reflected in the shift in NEE of both species (Fig. 1b). 
Fig. 1 Cool-season precipitation and NEE of Lehmann lovegrass and bush muhly plots under a normal conditions in 2009, and $\mathbf{b}$ El Niño conditions in 2010. Precipitation and NEE tick mark spacing are identical to allow comparison of both variables between panels. Normal year (c) and El Niño (d) cool-season maximum and minimum daily air temperature, and daily rooting zone volumetric soil water content $\left(\theta_{25 \mathrm{~cm}}\right)$ under normal (e) and El Niño conditions (f). NEE points are mean and SE of four independent measurements; $\theta_{25 \mathrm{~cm}}$ are the daily average of four plots measured every $0.5 \mathrm{~h}$

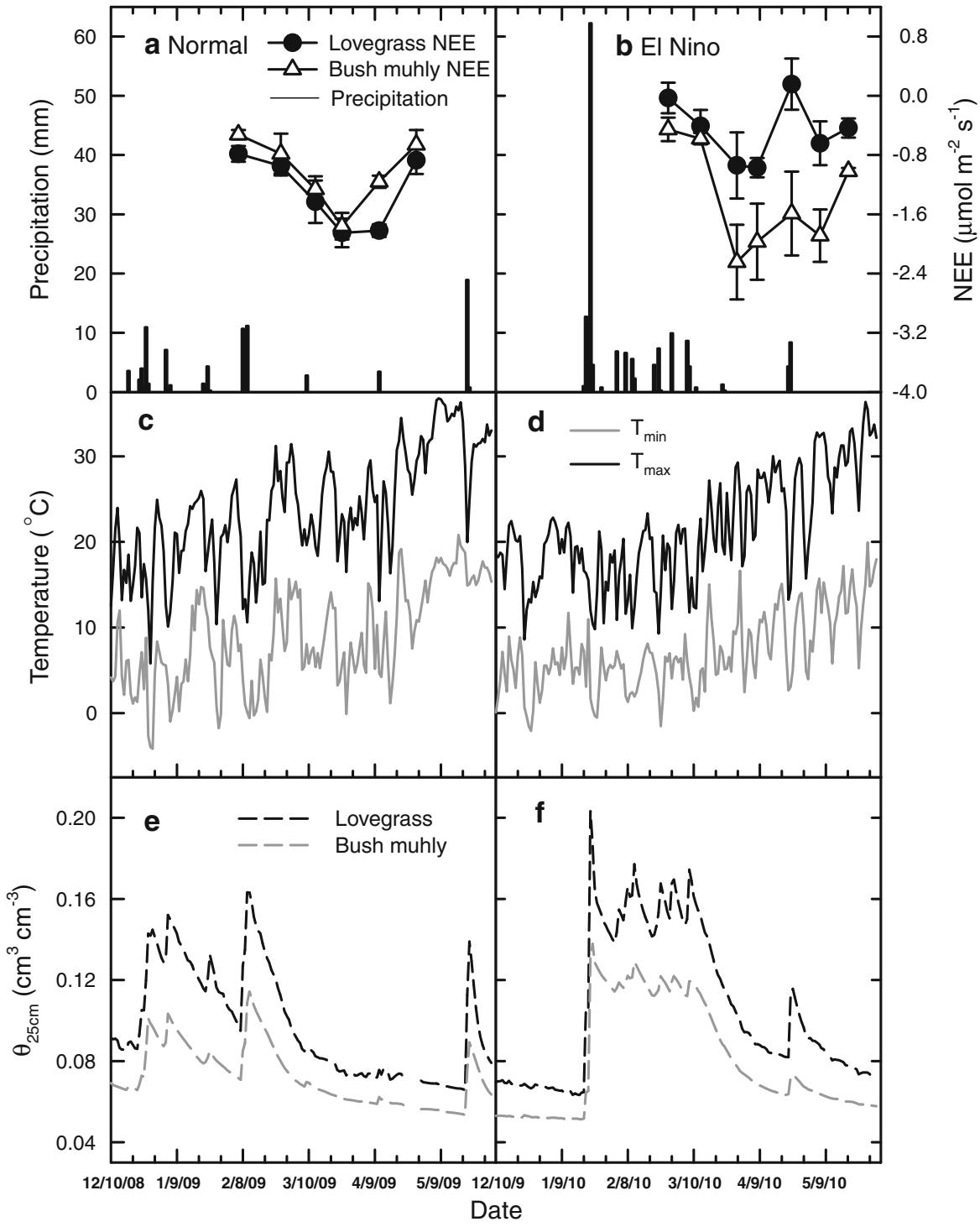

This followed colder $T_{\max }$ and $T_{\min }$ prevailing earlier in 2010 (Fig. 1d). In 2009, longer interstorm intervals led to 48 days with $T_{\max }$ exceeding $20{ }^{\circ} \mathrm{C}$ (Fig. 1c), compared to $24{ }^{\circ} \mathrm{C}$ in 2010 (Fig. 1d). However, $T_{\max }$ $\left(F_{1,333}=1.06 ; p=0.30\right)$ and $T_{\min }\left(F_{1,133}=0.11\right.$; $p=0.74)$ did not differ between the 2 years. However, linear regression showed $T_{\min }$ was well-correlated with $T_{\max } \quad\left(R^{2}=0.68 ; \quad F_{1,133}=695.09\right.$; $p \leq 0.001)$, and that the $T_{\min }: T_{\max }$ slope for 2009 $(0.92, \mathrm{MSE}=11.31)$ was significantly lower than in 2010 (slope $=1.21, \mathrm{MSE}=11.23 ; F_{1,331}=12.75$; $p=0.004$; Fig. 2). Thus, in 2009, lowest $T_{\min }$ were followed by highest $T_{\max }$ and higher $T_{\min }$ were followed by lower $T_{\max }$ than in 2010 (Fig. 2).
Table 1 Repeated-measures ANOVA $F$ test results comparing whole-plant carbon and water gas exchange of Lehmann lovegrass and bush muhly in growing periods following normal (2009) and El Niño (2010) conditions

\begin{tabular}{lccc}
\hline & $\operatorname{Spp}_{(1,6)}$ & $\operatorname{Year}_{(1,6)}$ & Spp $\times$ year $_{(1,6)}$ \\
\hline NEE & 2.97 & 1.99 & $\mathbf{2 3 . 3 1}$ \\
$R_{\text {eco }}$ & $\mathbf{1 0 . 7 4}$ & 0.30 & 5.13 \\
GEP & $\mathbf{6 . 4 9}$ & 0.15 & $\mathbf{1 3 . 5 6}$ \\
ET & 1.68 & $\mathbf{3 0 . 5 5}$ & 4.76 \\
T & 3.54 & 1.07 & $\mathbf{1 5 . 4 6}$ \\
T:ET & 4.61 & $\mathbf{2 4 . 6 4}$ & $\mathbf{7 . 3 5}$
\end{tabular}

Degrees freedom are presented parenthetically, bold results indicates significant differences at $p \leq 0.05$ 


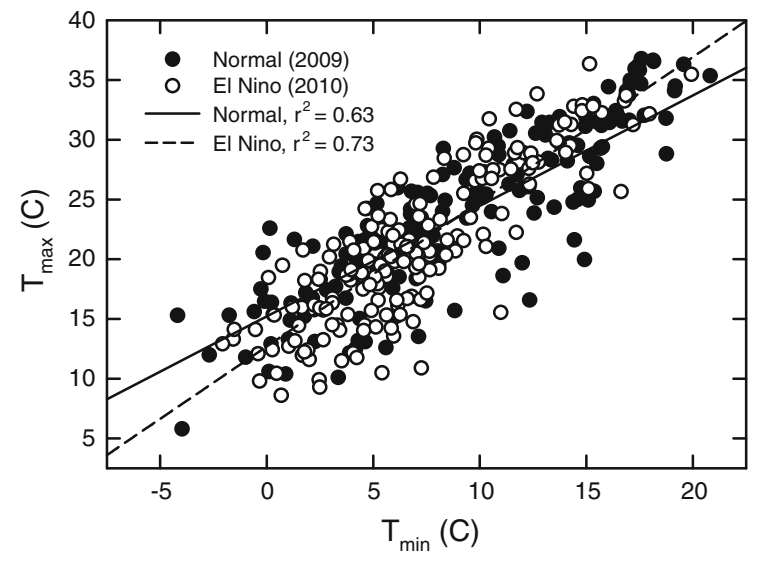

Fig. 2 Relationship between daily minimum $\left(T_{\min }\right)$ and maximum air temperatures $\left(T_{\max }\right)$ for normal (2009) and El Niñoyear conditions (2010)

$\theta_{25 \mathrm{~cm}}$ pooled across both species differed between $2009\left(9.2 \mathrm{~cm} \mathrm{~cm}^{-1} \pm 0.17 \mathrm{SE}\right.$; Fig. 1e) and 2010 $\left(10.4 \mathrm{~cm} \mathrm{~cm}^{-1} \pm 0.21 \mathrm{SE}\right.$; Fig. 1f $)\left(F_{1,496}=22.91\right.$; $p \leq 0.01)$, and was higher across lovegrass soil profiles (11.3 $\left.\mathrm{cm} \mathrm{cm}^{-1} \pm 0.20 \mathrm{SE}\right)$ compared to bush muhly $\left(8.4 \mathrm{~cm} \mathrm{~cm}^{-1} \pm 0.14\right.$ SE; $F_{1,496}=142.2$; $p \leq 0.001$ ), with no species-by-year interaction $\left(F_{1,496}=0.01 ; p=0.92\right)$.

Ecosystem respiration $\left(R_{\text {eco }}\right)$ varied significantly between lovegrass and bush muhly plots (Table 1), and were higher in bush muhly $\left(1.3 \mu \mathrm{mol} \mathrm{m}^{-2} \mathrm{~s}^{-1} \pm\right.$ $0.11 \mathrm{SE})$ than in lovegrass $\left(0.8 \mu \mathrm{mol} \mathrm{m} \mathrm{m}^{-2} \mathrm{~s}^{-1} \pm\right.$ $0.05 \mathrm{SE}$ ), with no differences between years or species-by-time interaction (Table 1), despite upregulation in lovegrass $R_{\text {eco }}$ in response to late-season rain in 2010 (Fig. 3a). Pooled across both years, bush muhly GEP $\left(2.5 \mu \mathrm{mol} \mathrm{m} \mathrm{m}^{-2} \mathrm{~s}^{-1} \pm 0.21 \mathrm{SE}\right)$ was higher than lovegrass plot GEP $(1.6 \mu \mathrm{mol}$ $\mathrm{m}^{-2} \mathrm{~s}^{-1} \pm 0.12 \mathrm{SE}$ ), with no significant differences in GEP between years, and a species-by-year interaction (Table 1). This interaction was due to bush muhly having higher GEP in $2010\left(2.9 \mu \mathrm{mol} \mathrm{m} \mathrm{m}^{-2} \mathrm{~s}^{-1} \pm\right.$ $0.34 \mathrm{SE})$ than lovegrass $\left(1.2 \mu \mathrm{mol} \mathrm{m} \mathrm{m}^{-2} \mathrm{~s}^{-1} \pm 0.14\right.$ SE; Scheffe's $F=29.0 ; p=0.012$ ), while both species had similar GEP in 2009 (Scheffe's $F=$ $0.06 ; p=0.82$; Fig. $3 b$ ). Despite higher peak GEP rates in bush muhly and lower peak GEP in lovegrass plots under El Niño conditions (Fig. 3b), there were no significant differences in GEP in lovegrass (Scheffe's
Fig. 3 a Ecosystem respiration $\left(R_{\text {eco }}\right)$, b GEP, c ET, and $\mathbf{d} \mathrm{T}$ of Lehmann lovegrass and bush muhly plots following normal (2009) and El Niño-year conditions (2010). Each point is the mean and SE of four independent measurements, made on the same plants for both years

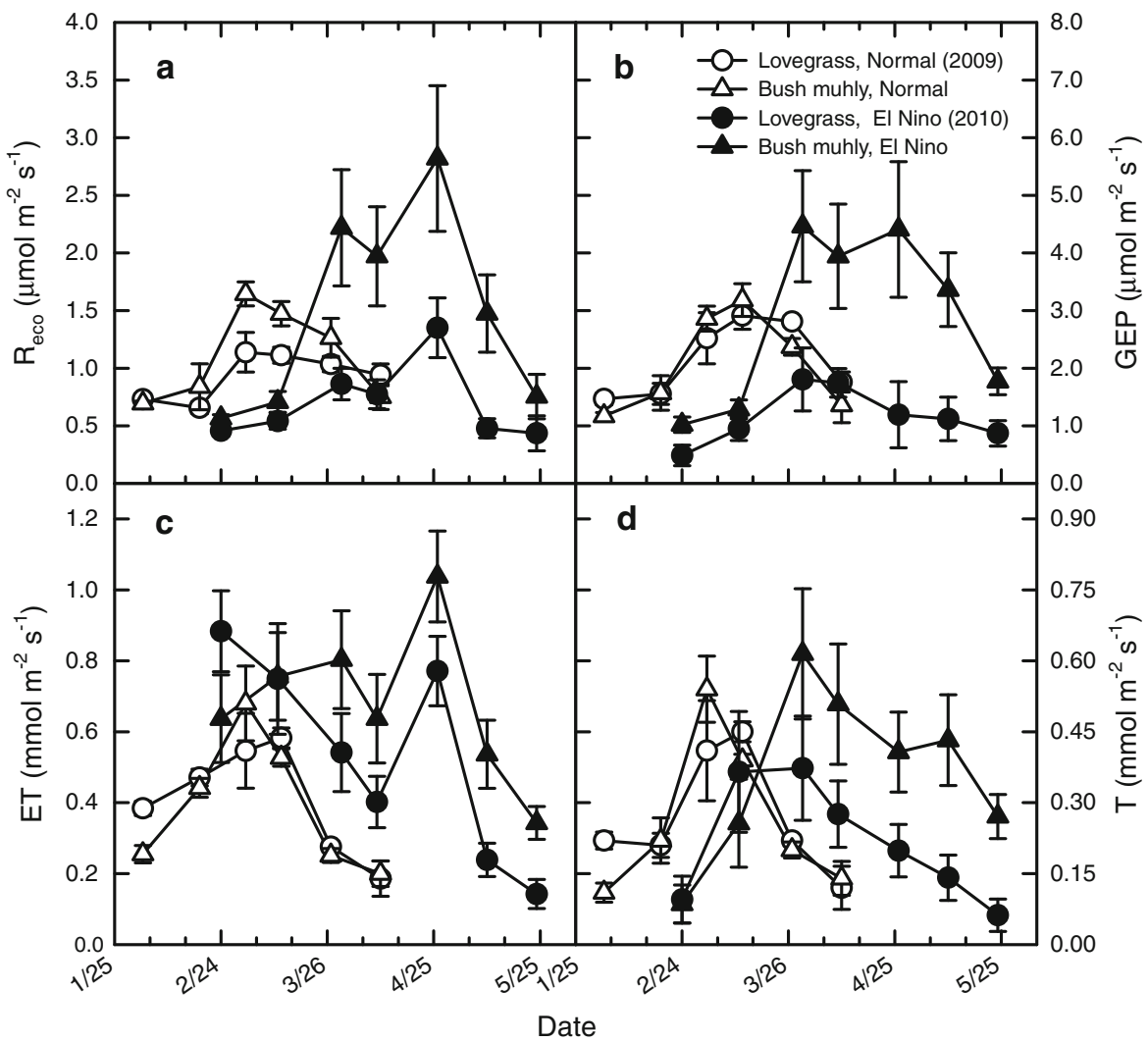


$F=9.0 ; p=0.06$ ) or bush muhly plots (Scheffe's $F=5.9 ; p=0.09$ ) between 2009 and 2010 .

ET did not differ between species, but did differ between years, with no species-by-year interaction (Table 1). ET was higher in $2010 \quad(0.61 \mathrm{mmol}$ $\mathrm{m}^{-2} \mathrm{~s}^{-1} \pm 0.040$ SE) than in $2009(0.40 \mathrm{mmol}$ $\mathrm{m}^{-2} \mathrm{~s}^{-1} \pm 0.026$ SE; Fig. 3c). Plant $\mathrm{T}$ also did not differ between species or years, but had a significant species-by-time interaction (Table 1), due to increases in bush muhly $\mathrm{T}$ from $2009\left(0.26 \mathrm{mmol} \mathrm{m}^{-2}\right.$ $\mathrm{s}^{-1} \pm 0.035$ SE) to $2010 \quad\left(0.38 \mathrm{mmol} \mathrm{m}^{-2} \mathrm{~s}^{-1}\right.$ $\pm 0.043 \mathrm{SE}$; Scheffe's $F=10.3 ; p=0.049$; Fig. 3d). Also, bush muhly $\mathrm{T}$ was greater than lovegrass $\left(0.20 \mathrm{mmol} \mathrm{m}^{-2} \mathrm{~s}^{-1} \pm 0.031 \mathrm{SE}\right)$ in 2010 (Scheffe's $F=24.9 ; p=0.02$ ), which was not the case in 2009, when bush muhly $\mathrm{T}$ was similar to lovegrass plots (0.28 mmol m $\mathrm{m}^{-2} \mathrm{~s}^{-1} \pm 0.029$ SE; Fig. 3d).

T:ET ratios differed between 2009 and 2010 (Table 1), with higher ratios in $2009(66.2 \% \pm 2.84$ $\mathrm{SE}$ and $64.9 \% \pm 3.54 \mathrm{SE}$ for lovegrass and bush muhly, respectively) than in $2010(42.2 \% \pm 4.77 \mathrm{SE}$ and $57.9 \% \pm 5.28$ SE lovegrass and bush muhly, respectively). Pooled T:ET were higher in bush muhly $(61.3 \% \pm 3.23 \mathrm{SE})$ compared to lovegrass plots $(52.4 \%, \pm 3.42 \mathrm{SE})$, with a species-by-time interaction (Table 1). 2010 lovegrass T:ET ratios were lower than 2009 levels (Scheffe's $F=28.7 ; p=0.01$ ), and were lower than 2010 bush muhly T:ET (Scheffe's $F=12.9 ; p=0.04$; Fig. 4 ). There were no differences in bush muhly ratios between 2009 and 2010 (Scheffe's $F=2.5 ; p=0.21$ ).

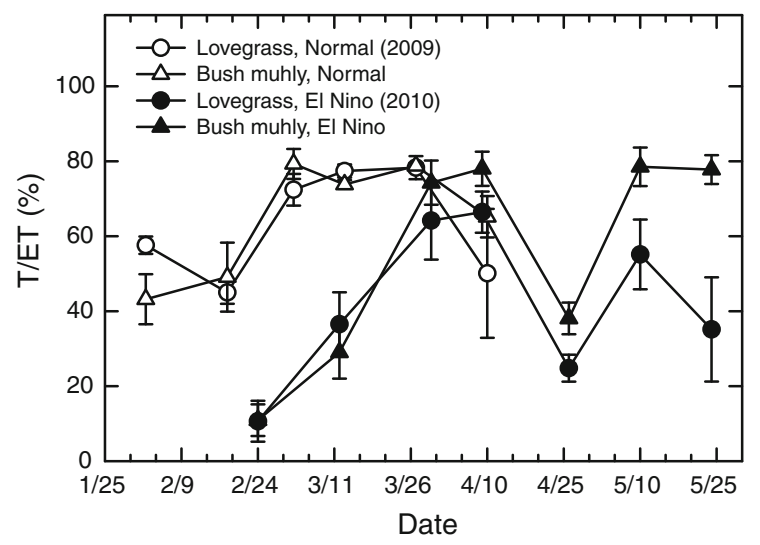

Fig. 4 Relative contributions of T to ET of Lehmann lovegrass and bush muhly plots under normal (2009) and El Niño-year (2010) conditions. Each point is the mean and SE of four independent measurements
GEP had a significant relationship with ET $\left(\mathrm{WUE}_{\mathrm{e}}\right.$ : $\mathrm{GEP}=1.07+1.96 * \mathrm{ET} \pm 0.44 \mathrm{SE} ; R^{2}=0.17$; $\left.F_{1,102}=20.23 ; p \leq 0.01\right)$, as did $\mathrm{T}\left(\mathrm{WUE}_{\mathrm{p}}\right.$ : GEP $=$ $0.49+5.72 * T \pm 0.42$ SE; $R^{2}=0.65 ; \quad F_{1,97}=$ 179.6; $p \leq 0.01)$, with differences between the four species/year combinations for $\mathrm{WUE}_{\mathrm{e}}\left(F_{3,79}=65.6\right.$; $p \leq 0.05)$ and WUE $_{\mathrm{p}}\left(F_{3,79}=423.3 ; p \leq 0.05\right)$. Lovegrass plot WUE $_{\mathrm{e}}$ decreased from 2009 $\left(1.88 \mu \mathrm{mol} \mathrm{mmol}^{-1}\right)$ to near-zero in 2010 (0.035 $\mu \mathrm{mol} \mathrm{mmol}{ }^{-1}$; Tukey's HSD $=11.9$; Fig. 5a), but did not change in bush muhly plots $(3.23 \mu \mathrm{mol}$ $\mathrm{mmol}^{-1}$ and $3.77 \mu \mathrm{mol} \mathrm{mmol}{ }^{-1}$ for 2009 and 2010 , respectively; Fig. 5c) (Tukey's HSD = 3.5). Lovegrass $\mathrm{WUE}_{\mathrm{e}}$ was lower than bush muhly $\mathrm{WUE}_{\mathrm{e}}$ in 2009 (Tukey's HSD = 8.68) and 2010 (Tukey's $\mathrm{HSD}=24.0$; Fig. 5a, c). Lovegrass $\mathrm{WUP}_{\mathrm{p}}$ did not change between $2009\left(3.64 \mu \mathrm{mol} \mathrm{mmol}{ }^{-1}\right)$ and 2010 $\left(3.18 \mu \mathrm{mol} \mathrm{mmol}^{-1}\right) \quad(\mathrm{HSD}=2.7$; Fig. $3 b)$, while bush muhly WUE $_{\mathrm{p}}$ increased in $2010(7.13 \mu \mathrm{mol}$ $\mathrm{mmol}^{-1}$ ) from 2009 (4.16 $\mu \mathrm{mol} \mathrm{mmol}{ }^{-1} ; \mathrm{HSD}=$ 5.2; Fig. 5d). In addition, $\mathrm{WUE}_{\mathrm{p}}$ of lovegrass plots were lower than bush muhly in $2009(\mathrm{HSD}=4.32)$ and 2010 (HSD = 5.2; Fig. 5b, d).

\section{Discussion}

Our results showed Lehmann's lovegrass is not better at using cool-season precipitation compared to the native grass, bush muhly; in fact, lovegrass performance was particularly poor following El Niñoenhanced winter precipitation (Fig. 1b). These results suggest the higher productivity considered an important contribution to the invasive success of this grass is not due to more effective use of cool-season precipitation, as has been conjectured (Anable et al. 1992; Frasier and Cox 1994; McClaran 2003; Geiger and McPherson 2005) is most probably attained in the summer monsoon-season. The low GEP and $R_{\text {eco }}$ of lovegrass in 2010 (Fig. 3) may have resulted from long-term inhibition of leaf-level photosynthetic or respiratory function following the colder maximum temperatures (Smith et al. 1997; Atkin and Tjoelker 2003) that occurred more frequently following similar $T_{\min }$ in 2010 (Fig. 2). In addition, leaf and tiller mortality following cold winter conditions, documented in biomass partitioning studies of Lehmann's lovegrass stands (Cox et al. 1990), may have affected photosynthetic and aboveground respiratory fluxes 
Fig. 5 Ecosystem water use efficiency $\left(\mathrm{WUE}_{\mathrm{e}}=\mathrm{GEP} / \mathrm{ET}\right)$ and whole-plant water use efficiency $\left(\mathrm{WUE}_{\mathrm{p}}=\mathrm{GEP} /\right.$ $T$ ) of Lehmann lovegrass (a and $\mathbf{b}$ for $\mathrm{WUE}_{\mathrm{e}}$ and $\mathrm{WUE}_{\mathrm{p}}$, respectively) and bush muhly plots (c and d for $\mathrm{WUE}_{\mathrm{e}}$ and $\mathrm{WUE}_{\mathrm{p}}$, respectively) under normal $(2009$, closed symbols) and El Niño-year cool-season active conditions (2010, open symbols); *significant individual regressions within a year $(p<0.05)$

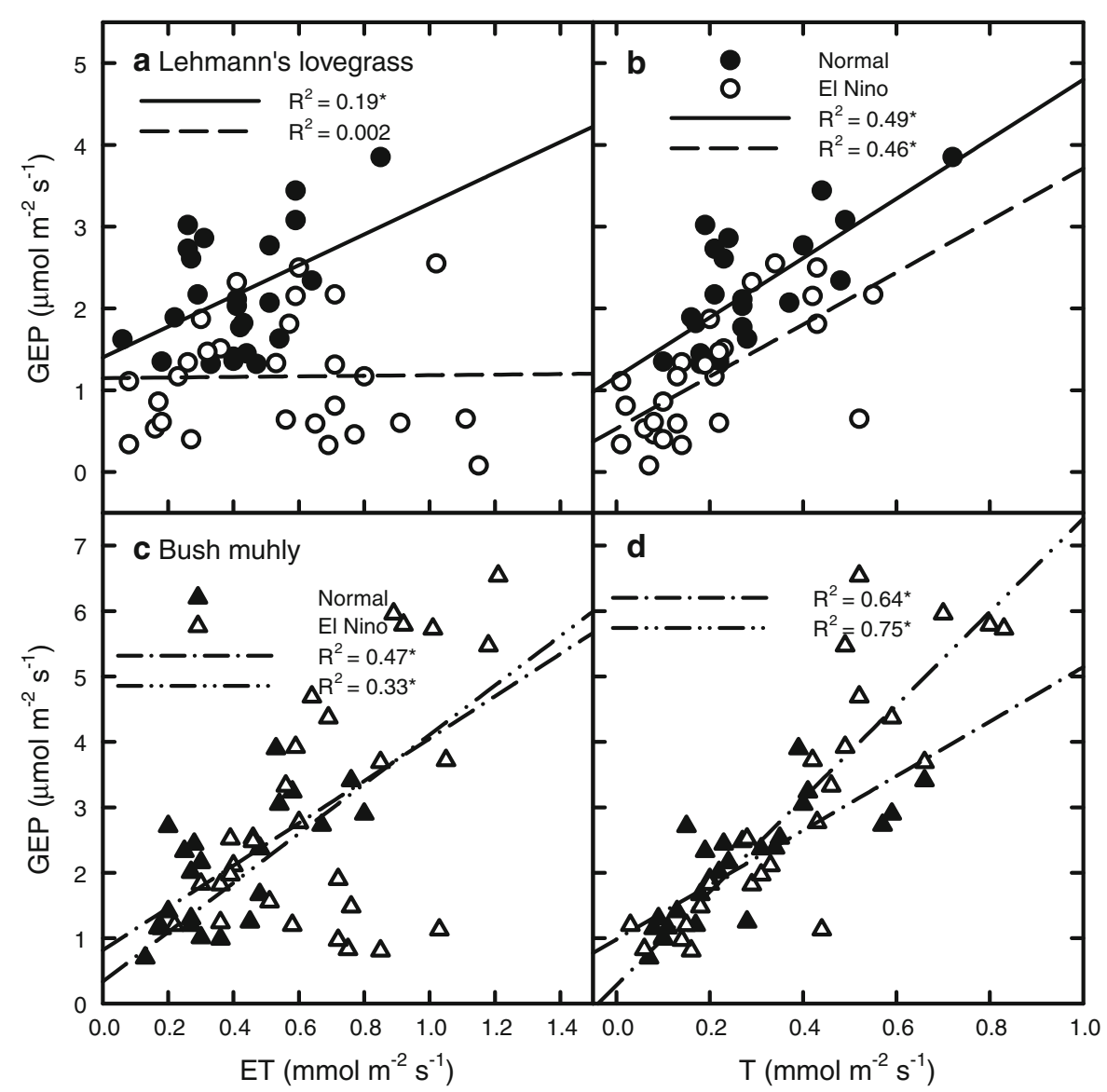

(Flanagan et al. 2002; Flanagan and Johnson 2005). Such aboveground adjustments have concurrent belowground changes (Fernandez and Reynolds 2000), which could lower total root respiration, a dominant component in soil respiration in grassland systems (Knapp et al. 1998; Flanagan et al. 2002). Lower $R_{\text {eco }}$ in Lehmann lovegrass plots may also reflect lower heterotrophic respiration; lovegrass stands produce less litter (Cox et al. 1990; Yepez et al. 2005), which could limit substrate availability to heterotrophic activity important to aridland respiratory fluxes (Sponseller 2007; Jenerette et al. 2008).

Following high precipitation in 2010 (Fig. 1b), ET was similar between bush muhly and Lehmann's lovegrass plots (Fig. 4), but not due to higher $\mathrm{T}$ contributions, contrary to expectations of Frasier and Cox (1994). Lower $\theta_{25 \mathrm{~cm}}$ under bush muhly was also noted in the summer monsoon (Hamerlynck et al. 2010), and may indicate lower water extraction by the invasive grass, contrary to patterns in water-use comparing invasive and native bunchgrasses in cold desert systems
(Anderson et al. 1987; Anderson and Toft 1993). However, despite locating our site on a distinct geomorphic surface to limit soil heterogeneity, the lack of convergent $\theta_{25 \mathrm{~cm}}$ during prolonged dry periods in our study (Fig. 1e, f) suggests that, even though soils under these plants have similar $\theta$ and soil water potential relationships (Hamerlynck et al. 2010, 2011), there may be differences in soil bulk density that could affect $\theta_{25 \mathrm{~cm}}$ obtained using TDR (Jacobsen and Schjønning 1993) that drove these differences, and not plant water use.

Similar to GEP, the lower T:ET in lovegrass plots may reflect stomatal limitations concurrent with physiological down-regulation (Smith et al. 1997; Taub 2000; Atkin and Tjoelker 2003), or reductions in live biomass (Cox et al. 1990). However, reductions in lovegrass T from 2009 to 2010 were modest (Fig. 4), suggesting that similar ET between lovegrass plots with bush muhly plots was sustained by higher soil $\mathrm{E}$ (Fig. 5). This is consistent with warm-season chamber- and lysimeter-based studies showing greater soil E contributions to ET under lovegrass dominance, 
which have been attributed to lower litter accumulation (Huxman et al. 2004; Yepez et al. 2005) and lower plant T (Moran et al. 2009). These differences have distinct impact on differences seen in water-use efficiency. In lovegrass, high ET at low T and GEP drove a large drop in $\mathrm{WUE}_{\mathrm{e}}$ compared to 2009 levels, despite small differences in whole-plant water-use efficiency (WUE ${ }_{p}$ ) between the 2 years (Fig. 5a, b). In contrast, $W_{U} E_{e}$ in bush muhly plots was constant from year to year (Fig. 5c), while $\mathrm{WUE}_{\mathrm{p}}$ increased from 2009 to 2010, concurrent with higher GEP and T (Fig. 3b, d). Thus, soil $\mathrm{E}$ drove the divergence in $\mathrm{WUE}_{\mathrm{e}}$ in lovegrass, and convergence in $\mathrm{WUE}_{\mathrm{e}}$ in bush muhly plots. These findings suggest cool-season $\mathrm{WUE}_{\mathrm{e}}$ and productivity is likely to show greater interannual variation in lovegrass-dominated areas, but also highlights the importance of soil contributions to overall ecosystem WUE, which integrates leaf- and stand-level processes, and is considered an important metric of ecosystem stability and resilience to environmental variation (Monson et al. 2010).

Warmer cool-season temperatures predicted for the western US (Easterling et al. 2000a, 2000b; Mote et al. 2005; Christensen and Hewitson 2007; Seager et al. 2007) may relax the cool-season constraints apparent to Lehmann lovegrass activity, facilitating the spread of this exotic grass across broader ranges of latitude and elevation (Geiger et al. 2003; Geiger and McPherson 2005). This could especially be true if $T_{\max }$ and $T_{\min }$ regimes similar to 2009 (Fig. 2) were to accompany ENSO-enhanced rains. However, future ENSO may also result in temperature regimes similar to 2010 with lower $T_{\max }$ at low $T_{\min }$ (Fig. 2) which could favor native grasses such as bush muhly that respond well to ENSO-enhanced precipitation. In addition, it should be noted the maximum cool-season NEE, GEP, and $R_{\text {eco }}$ of bush muhly and Lehmann's lovegrass are one-quarter to one-third of levels attained during the summer monsoon (Huxman et al. 2004; Potts et al. 2006; Hamerlynck et al. 2010). This suggests cool-season carbon uptake, even following a strong ENSO year like 2010, is not overly important to annual carbon balance in semiarid grasslands, as suggested in biomass-based studies (Cox et al. 1990; Muldavin et al. 2008). However, augmenting coolseason water can dramatically increase subsequent monsoon-season growth and cover of warm-season grasses (Robertson et al. 2010), which suggest coolseason rain could modulate increased productivity observed under experimentally induced warmer and wetter monsoon conditions (Patrick et al. 2007; Collins et al. 2010).

Deeper soil moisture recharge is principally attained during the cool-season, and frequently enhanced under ENSO conditions (Cable 1980; Seyfried et al. 2005; Huxman et al. 2005; Holmgren et al. 2006), which could reduce the severity and length of the prolonged dry period that typically occurs between cool- and warm-season growing periods (Neilson 1987). This has been observed in field experiments simulating larger, more widely spaced storms, which increased semiarid grassland productivity by reducing stress during interstorm periods (Heisler-White et al. 2008, 2009) or extended warm-season activity into the fall (Patrick et al. 2007). Thus, ENSO conditions could favor higher productivity of native grasses like bush muhly that might be better "primed" for the monsoon, offsetting the strong monsoon-season NEE responses observed in Lehmann's lovegrass (Hamerlynck et al. 2010).

The magnitude of change in the relative fractions of $\mathrm{E}$ and $\mathrm{T}$ to ET, especially under conditions of higher water availability (Fig. 4), and subsequent changes in $\mathrm{WUE}_{\mathrm{e}}$ (Fig. 5a,c) represents a fundamental shift in ecosystem function usually associated with dramatic changes in vegetative structure, such as woody plant encroachment into grassland systems, which increase E (Huxman et al. 2005), or replacement of shrubs with annual grasses, which can increase T contributions (Prater and DeLucia 2006; though see Kurc and Small 2003). As Prater and DeLucia (2006) noted, such changes in energy partitioning can alter ecosystem processes such as litter turnover, nutrient cycling (Chen and Stark 2000; Ogle et al. 2004), and soil surface and groundwater dynamics (Huxman et al. 2005; Prater and DeLucia 2006). Indeed, it may be that reductions in biotic diversity associated with Lehmann's lovegrass dominance (Bock et al. 1986; Flanders et al. 2006) reflect the cumulative ecological effects of the shifts in controls to ET and coupled carbon dynamics noted in warm-season (Huxman et al. 2004; Yepez et al. 2005; Moran et al. 2009) and this cool-season study.

\section{References}

Anable ME, McClaran MP, Ruyle GB (1992) Spread of introduced Lehmann lovegrass Eragrostis lehmanniana Nees. in Southern Arizona. Biol Conserv 61:181-188

Anderson JE, Toft NL (1993) Depletion of soil moisture by two cold desert bunchgrasses and effects on photosynthetic performance. Great Basin Nat 53:97-106 
Anderson JE, Shumar ML, Toft NL, Nowak RS (1987) Control of the soil water balance by sagebrush and three perennial grasses in a cold-desert environment. Arid Soil Res Rehabil 1:229-244

Atkin OK, Tjoelker MG (2003) Thermal acclimation and the dynamic response of plant respiration to temperature. Trends Plant Sci 8:343-351

Bock CE, Bock JH, Jepson KL, Ortega JC (1986) Ecological effects of planting African lovegrasses in Arizona. Nat Geogr Res 2:456-463

Breckenfeld DJ, Robinett D (2003) Soil and ecological sites of the Santa Rita Experimental Range. In: McClaran MP, PF Ffolliot, Edminster CB (eds) Santa Rita Experimental Range: 100 years (1903 to 2003) of accomplishments and contributions, conference proceedings Oct 30-Nov 1, 2003, Tucson AZ, pp 157-165. USDA Rocky Mountain Research Station Proceedings 30, Ogden, UT

Cable DR (1980) Seasonal patterns of soil water recharge and extraction on semidesert ranges. J Range Manage 33:9-15

Caldwell MM, Richards JH, Johnson DA, Nowak RS, Dzurec RS (1981) Coping with herbivory: photosynthetic capacity and resource allocation in two semiarid Agropyron bunchgrasses. Oecologia 50:14-24

Caldwell MM, Dean TJ, Nowak RS, Dzurec RS, Richards JH (1983) Bunchgrass architecture, light interception and water use efficiency: assessment by fiber optic point quadrats and gas exchange. Oecologia 59:178-184

Chen J, Stark JM (2000) Plant species effects on carbon and nitrogen cycling in a sagebrush-crested wheatgrass soil. Soil Biol Biochem 32:47-57

Christensen JH, Hewitson B (2007) Regional climate projections. In: Solomon S, Qin D, Manning M (eds) Climate Change 2007: The Physical Science Basis. Contribution of working group I to the Fourth Assessment Report of the Intergovernmental Panel on Climate Change, pp 487-940. Cambridge University Press, Cambridge

Collins SL, Fargione JE, Crenshaw CL, Nonaka E, Elliot JR, Xia Y, Pockman WT (2010) Rapid plant community composition responses during summer monsoon to nighttime warming in a northern Chihuahuan Desert grassland. J Arid Environ 74:611-617

Cox JR, Ruyle GB (1996) Influence of climate, soil and grazing of the distribution of Lehmann lovegrass. In: Tellman B, Finch DM, Edminster C, Hamre R (eds) The future of arid grasslands: identifying issues, seeking solutions, conference proceedings October 9-13, 1996, Tucson AZ, pp 150-154. USDA Forest Service Rocky Mountain Research Station Proceedings 4, Ogden UT

Cox JR, Ruyle GB, Roundy BA (1990) Lehmann lovegrass in southeastern Arizona: biomass production and disappearance. J Range Manage 43:367-372

DeFalco LA, Fernandez GCJ, Nowak RS (2007) Variation in the establishment of a non-native annual grass influences competitive interactions within Mojave Desert perennials. Biol Invasions 9:293-307

Easterling DR, Meehl GA, Parmesan C, Changnon SA, Karl TR, Mearns LO (2000a) Climate extremes: observations, modeling, and impacts. Science 289:2068-2074

Easterling DR, Evans JL, Groisman PY, Karl TR, Kunkel KE, Ambenje P (2000b) Observed variability and trends in extreme climate events: a brief review. Bull Am Meteorol Soc 81:417-425

Fernandez RJ, Reynolds JF (2000) Potential growth and drought tolerance of eight desert grasses: lack of a trade-off? Oecologia 123:90-98

Flanagan LB, Johnson BG (2005) Interacting effects of temperature, soil moisture and plant biomass on ecosystem respiration in a northern temperate grassland. Ag Forest Meteorol 130:237-253

Flanagan LB, Wever LA, Carlson PJ (2002) Seasonal and interannual variation in carbon dioxide exchange and carbon balance in a northern temperate grassland. Glob Change Biol 8:599-615

Flanders AA, Kuvlesky WP, Ruthven DC, Zaiglin RE, Bingham RL, Fulbright TE, Hernandez F, Brennan LA (2006) Effects of invasive exotic grasses on south Texas rangeland breeding birds. Auk 123:171-182

Frasier GW, Cox JR (1994) Water balance in pure stands of Lehmann lovegrass. J Range Manage 47:373-378

Geiger EL, McPherson GR (2005) Response of semi-desert grasslands invaded by non-native grasses to altered disturbance regimes. J Biogeogr 32:895-902

Geiger EL, Mau-Crimmins T, Schussman H (2003) Spread of a nonnative grass across southern Arizona: Multiple data sources to monitor change. In: McClaran MP, Ffolliot PF, Edminster CB (eds) Santa Rita Experimental Range: 100 years (1903 to 2003) of accomplishments and contributions, conference proceedings Oct 30-Nov 1, 2003, Tucson AZ, pp 116-120. USDA Rocky Mountain Research Station Proceedings 30, Ogden, UT

Hamerlynck EP, Scott RL, Moran MS, Keefer TO, Huxman TE (2010) Growing season ecosystem- and leaf-level gas exchange of an exotic and native semiarid bunchgrass. Oecologia 163:561-570

Hamerlynck EP, Scott RL, Moran MS, Schwander AM, Connor E, Huxman TE (2011) Inter- and under-canopy soil water, leaf-level and whole-plant gas exchange of a semiarid perennial $\mathrm{C}_{4}$ grass. Oecologia 165:17-29

Heisler-White JL, Knapp AK, Kelly EF (2008) Increasing precipitation event size increases aboveground net primary productivity in a semi-arid grassland. Oecologia 158:129-140

Heisler-White JL, Blair JM, Kelly EF, Harmoney K, Knapp AK (2009) Contingent productivity responses to more extreme rainfall regimes across a grassland biome. Glob Change Biol 15:2894-2904

Holmgren M, Lopez BC, Gutierrez JR, Squeo FA (2006) Herbivory and plant growth rate determine the success of El Niño Southern Oscillation-driven tree establishment in semiarid South America. Glob Change Biol 12:2263-2271

Huenneke LF, Anderson JP, Remmenga M, Schlesinger WH (2002) Desertification alters patterns of aboveground primary production in Chihuahuan ecosystems. Glob Change Biol 8:247-264

Huxman TE, Smith SD (2001) Photosynthesis in an invasive grass and native forb at elevated $\mathrm{CO}_{2}$ during an El Niño year in the Mojave Desert. Oecologia 128:193-201

Huxman TE, Cable JM, Ignace DD, Eilts JA, English NB, Weltzin J, Williams DG (2004) Response of net ecosystem gas exchange to a simulated precipitation pulse in a semi- 
arid grassland: the role of native versus non-native grasses and soil texture. Oecologia 141:295-305

Huxman TE, Wilcox BP, Breshears DD, Scott RL, Snyder KA, Small EE, Hultine K, Pockman WT, Jackson RB (2005) Ecohydrological implications of woody plant encroachment. Ecology 86:308-319

Jacobsen OH, Schjønning P (1993) A laboratory calibration of time domain reflectometry for soil water measurement including effects of bulk density and texture. J Hydrol 151:147-157

Jenerette GD, Scott RL, Huxman TE (2008) Whole ecosystem metabolic pulses following precipitation events. Funct Ecol 22:924-930

Knapp AK, Conard JL, Blair JM (1998) Determinants of soil $\mathrm{CO}_{2}$ flux from a sub-humid grassland: effect of fire and fire history. Ecol Appl 8:760-770

Kurc SA, Small EE (2004) Dynamics of evapotranspiration in semiarid grassland and shrubland ecosystems during the summer monsoon season, central New Mexico. Water Resour Res 40:W09305

Marshall JD, Blair JM, Peters DPC, Okin G, Rango A, Williams M (2008) Predicting and understanding ecosystem responses to climate change at continental scales. Front Ecol Environ 6:273-280

McClaran MP (2003) A century of vegetation change on the Santa Rita Experimental Range. In: McClaran MP, Ffolliot PF, Edminster CB (eds) Santa Rita Experimental Range: 100 years (1903 to 2003) of accomplishments and contributions, conference proceedings Oct 30-Nov 1, 2003, Tucson AZ, pp 16-33. USDA Rocky Mountain Research Station Proceedings 30, Ogden, UT

McKee TB, Doesken NJ, Kleist J (1993) The relationship of drought frequency and duration to time scale. In: Proceedings of the eighth conference on applied climatology, pp 17-22. Am Meteorol Soc, Boston, MA

Miller RF, Donart GB (1981) Response of Muhlenbergia porteri Scribn. to season of defoliation. J Range Manage 34:91-94

Monson RK, Prater MR, Hu J, Burns SP, Sparks JP, Sparks KL, Scott-Denton LE (2010) Tree species effects on ecosystem water-use efficiency in a high-elevation, subalpine forest. Oecologia 162:491-504

Moran MS, Scott RL, Hamerlynck EP, Green KN, Emmerich WE, Holifield-Collins CD (2009) Soil evaporation response to Lehmann lovegrass (Eragrostis lehmanniana) invasion in a semiarid watershed. Agric For Meteorol 149:2133-2142

Mote PW, Hamlet AF, Clark MP, Lettenmaier DP (2005) Declining mountain snowpack in western North America. Bull Am Meteorol Soc 86:39-49

Muldavin EH, Moore DI, Collins SL, Wetherill KR, Lightfoot DC (2008) Aboveground net primary production dynamics in a northern Chihuahuan Desert ecosystem. Oecologia 155:123-132

Neilson RP (1987) Biotic regionalization and climatic controls in western North America. Vegetatio 70:135-147
Ogle SM, Ojima D, Reiners WA (2004) Modeling the impact of exotic annual brome grasses on soil organic storage in northern mixed-grass prairie. Biol Invasions 6:365-377

Patrick L, Cable J, Potts D, Ignace D, Gafford-Barron G, Griffith A, Alpert H, Van Gestel N, Robertson T, Huxman TE, Zak J, Loik ME, Tissue D (2007) Effects of an increase in summer precipitation on leaf, soil, and ecosystem fluxes of $\mathrm{CO}_{2}$ and $\mathrm{H}_{2} \mathrm{O}$ in a sotol grassland in Big Bend National Park, Texas. Oecologia 151:704-718

Potts DL, Huxman TE, Cable JM, English NB, Ignace DD, Eilts JA, Mason MJ, Weltzin JF, Williams DG (2006) Antecedent moisture and seasonal precipitation influence the response of canopy-scale carbon and water exchange to rainfall pulses in a semi-arid grassland. New Phytol 170:849-860

Prater MR, DeLucia EH (2006) Non-native grasses alter evapotranspiration and energy balance in Great Basin sagebrush communities. Agric For Meteorol 139:154-163

Robertson TR, Zak JC, Tissue DT (2010) Precipitation magnitude and timing differentially affect species richness and plant density in the sotol grassland of the Chihuahuan Desert. Oecologia 162:185-197

Scott RL, Shuttleworth WJ, Keefer TO, Warrick AW (2000) Modeling multiyear observations of soil moisture recharge in the semiarid American Southwest. Water Resour Res 36:2233-2247

Seager R, Ting M, Held I, Kushnir Y, Lu J, Vecchi G, Huang HP, Harnik N, Leetmaa A, Ngar-Cheung L, Li C, Velez J, Naik N (2007) Model projections of an imminent transition to a more arid climate in Southwestern North America. Science 316:1181-1184

Seyfried MS, Schwinning S, Walvoord MA, Pockman WT, Newman BD, Jackson RB, Phillips FM (2005) Ecohydrological control of deep drainage in arid and semiarid regions. Ecology 86:277-287

Sheppard PR, Comrie AC, Packin GD, Angersbach K, Hughes MK (2002) The climate of the US southwest. Climate Res 21:219-238

Smith SD, Monson RM, Anderson JE (1997) Physiological ecology of North American Desert plants. Springer, Berlin

Sponseller RA (2007) Precipitation pulses and soil $\mathrm{CO}_{2}$ fluxes in a Sonoran Desert ecosystem. Glob Change Biol 13:426-436

Taub DR (2000) Climate and the U.S. distribution of $\mathrm{C}_{4}$ grass subfamilies and decarboxylation variants of $\mathrm{C}_{4}$ photosynthesis. Am J Bot 87:1211-1215

Williams DG, Baruch Z (2000) African grass invasion in the Americas: ecosystem consequences and the role of ecophysiology. Biol Invasions 2:123-140

Yepez EA, Huxman TE, Ignace DD, English NB, Weltzin JF, Castellanos AE, Williams DG (2005) Dynamics of transpiration and evaporation following a moisture pulse in semiarid grassland: a chamber-based isotope method for partitioning flux components. Agric For Meteorol 132:359-376

Zar JH (1974) Biostatistical analysis. Prentice-Hall, Englewood Cliffs, p 215 